\title{
Spatial and Temporal Variations of the Particulate Matter in Riyadh City, Saudi Arabia
}

\author{
Abdullah S. Modaihsh, Fahd N. Al-Barakah, Mahmoud E. A. Nadeem, Mohamed O. Mahjoub* \\ Department of Soil Science, College of Food and Agricultural Sciences, King Saud University, Riyadh, \\ Kingdom of Saudi Arabia \\ Email: "osmanmahjoub@gmail.com
}

Received 22 October 2015; accepted 24 November 2015; published 27 November 2015

Copyright (C) 2015 by authors and Scientific Research Publishing Inc.

This work is licensed under the Creative Commons Attribution International License (CC BY). http://creativecommons.org/licenses/by/4.0/

c. (i) Open Access

\begin{abstract}
Mass concentrations of $\mathrm{PM}_{10}$ and $\mathrm{PM}_{2.5}$ for January 2012 up to October 2013 were measured at two sites; a suburban area, Riyadh airport (AP) and an urban area, King Fahd road district (KF) (densely trafficked site). Daily concentrations of both $\mathbf{P M}_{10}$ and $\mathbf{P M}_{2.5}$ measured at these two sites were

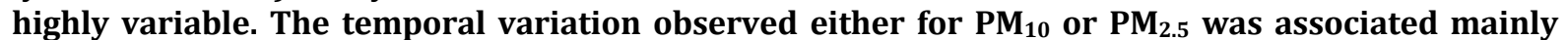
with the dust events. The annual pattern of $\mathbf{P M}_{10}$ and $\mathbf{P M}_{2.5}$ at the AP station shows a significant increase in spring and summer (dusty seasons) where monthly mean concentrations of up to 696 $\mu \mathrm{g} \cdot \mathrm{m}^{-3} \mathbf{P M}_{10}$ were recorded in March. $\mathbf{P M}_{10}$ concentrations during winter months are significantly lower, with $65 \mu \mathrm{g} \cdot \mathrm{m}^{-3}$ measured in November and $78 \mu \mathrm{g} \cdot \mathrm{m}^{-3}$ measured in December. January exhibits $\mathbf{P M}_{10}$ concentrations little above $100 \mu \mathrm{g} \cdot \mathrm{m}^{-3}$. Both $\mathbf{P M}_{10}$ and $P M_{2.5}$ showed substantial variations at these two monitoring stations during the study period. In the urban station (King Fahd), average annual $\mathrm{PM}_{10}$ varied by up to roughly a factor of two. This variation implies that local emission sources in this site often contribute much (i.e. greater than half) of the $\mathbf{P M}_{10}$ mass on annual average. The variation of monthly (temporal) mean $\mathrm{PM}_{10}$ at $\mathrm{KF}$ station showed more or less similar results to the AP station. Higher concentrations were observed during spring and summer $(12 \%, 17 \%$ and 13\% in Feb., March and April respectively and 17, 15\% during June and July). Starting from September and October, $\mathrm{PM}_{10}$ concentrations started to drop to $7 \%$ and $8 \%$ respectively. The relationships between the mean values of suspended particle concentrations and meteorological variables (relative humidity ambient temperature and wind speed) were analyzed. The results demonstrate that the influence of weather factors upon dust particulates is largely inconclusive. However, At KF station a moderate positive correlation was observed between wind speed and PM.
\end{abstract}

\section{Keywords}

$\mathbf{P M}_{10}, \mathbf{P M}_{2.5}$, Meteorological Data, Saudi Arabia, Riyadh

\footnotetext{
"Corresponding author.
}

How to cite this paper: Modaihsh, A.S., Al-Barakah, F.N., Nadeem, M.E.A. and Mahjoub, M.O. (2015) Spatial and Temporal Variations of the Particulate Matter in Riyadh City, Saudi Arabia. Journal of Environmental Protection, 6, 1293-1307. 


\section{Introduction}

Increased knowledge of the impact of suspended particulate matter on human health has significantly resulted in growing concern over the so-called particulate matter, in recent years. Since 1997, researches on air pollution have considered aerosols as one of the six major air pollutants [1]. Elevated particle concentration is strongly linked to increased mortality and morbidity [2]. According to their origin, particulate matters have been divided into natural and anthropogenic aerosols [3]. The major sources of anthropogenic aerosols include fuel combustion from automobiles, power plants, wood burning, industrial processes, and diesel powered vehicles such as buses and trucks. Soil-derived (mineral) dust particles can be a major part of the atmospheric $\mathrm{PM}_{2.5}$ and $\mathrm{PM}_{10}$ concentrations [4]. In the Kingdom of Saudi Arabia, studies of PM concentrations were extensively studied in Makkah, especially during the Hajj period when usually more than two million people visited the city to perform Hajj [5]-[7]. Recently, a brief review of the studies conducted in Saudi Arabia was presented [8]. To address the issue of atmospheric particulate matter in Riyadh city, El-Shobokshy [9] [10] conducted his pioneering study on particulate pollution in Saudi Arabia, but his studies concentrated only on atmospheric lead-pollution in the city of Riyadh. In 1990, investigation on the influence of meteorology on the concentration of inhalable particulate which was usually observed in the atmosphere of Riyadh at high concentrations was undertaken [11]. However, the studies mentioned above were based on limited number of samples. A relatively detailed study on PM samples collected from June 2006 to May 2007 showed that the PM concentrations were higher for PM PMmpared $_{10}$ to $\mathrm{PM}_{2.5}$, indicating that the major PM source was local dust [12]. A recent study showed that PM concentration was approximately 3 times higher than the country’s ambient air quality standards respectively. In addition, this study demonstrated that summer vs. winter comparison showed that PM concentrations were approximately 84\% higher in summer [13].

The primary goal of this study was to carry out a comprehensive characterization of $\mathrm{PM}_{1}$, and $\mathrm{PM}_{2.5}$ and provide the scientific background for further control of air pollution at Riyadh and to develop effective strategies to reduce the ambient deposition and concentrations of those pollutants to the city.

\section{Methods}

Traditional method of $\mathrm{PM}_{10}$ dust measurement is based on a weight to volume measurement, where by the dust is collected on a filer and subsequently weighed. This method requires a rigid adherence to time consuming procedures. With the finer dust size fraction introduction $\left(\mathrm{PM}_{2.5}, \mathrm{PM}_{1}\right)$ the problem is negligible mass compared to the large numbers of these particles. For these reason a newly developed Aerosol Spectrometer will be introduced for measurement of various PM particulates.

In this study, the concentrations of coarse $\left(\mathrm{PM}_{10}\right)$, and fine $\left(\mathrm{PM}_{2.5}\right)$, particulate matter were measured using a Grimm model EDM 365 aerosol spectrometer (Grimm Aerosol Technique GmbH, Airing, Germany). The device, an optical particle counter (OPC), is an instrument for real-time measurement of particulate matter. The particle size analyzer/dust monitor determines the dust-concentration (counts/liter) through the optical-lightscattering method directly; however, the mass concentration is determined by extrapolation. The calculated mass concentration may be corrected to the specific aerosol measured with the gravimetric-correction factor (C-Factor). The advantages of this instrument over other real-time measurement instruments, such as TEOM or DMA devices, are its convenience, its low maintenance requirements, and its ability to run for long periods without specific supervision. The ability to measure particulate matter concentrations in time intervals ranging from $1 \mathrm{~s}$ to $60 \mathrm{~min}$ is considered to be another advantage offered by the instrument. The validity of the measurements performed by the instrument has been evaluated by several studies [14]. The dust monitor was installed on the roof of the Meteorology and Environmental building near Riyadh airport. The dust monitor runs 24 hours a day continuously.

\section{Results and Discussion}

\subsection{Seasonal and Monthly Variability in PM Concentrations}

\subsubsection{Airport Station}

The monthly variation of $\mathrm{PM}_{10}$ concentrations as obtained from the daily mean recordings across the whole study period (February 2012 to January 2013) is shown in Figure 1. Results indicate that the highest PM concentrations occurs mainly in February, March and April, which is the period with the most frequent dust-storm 


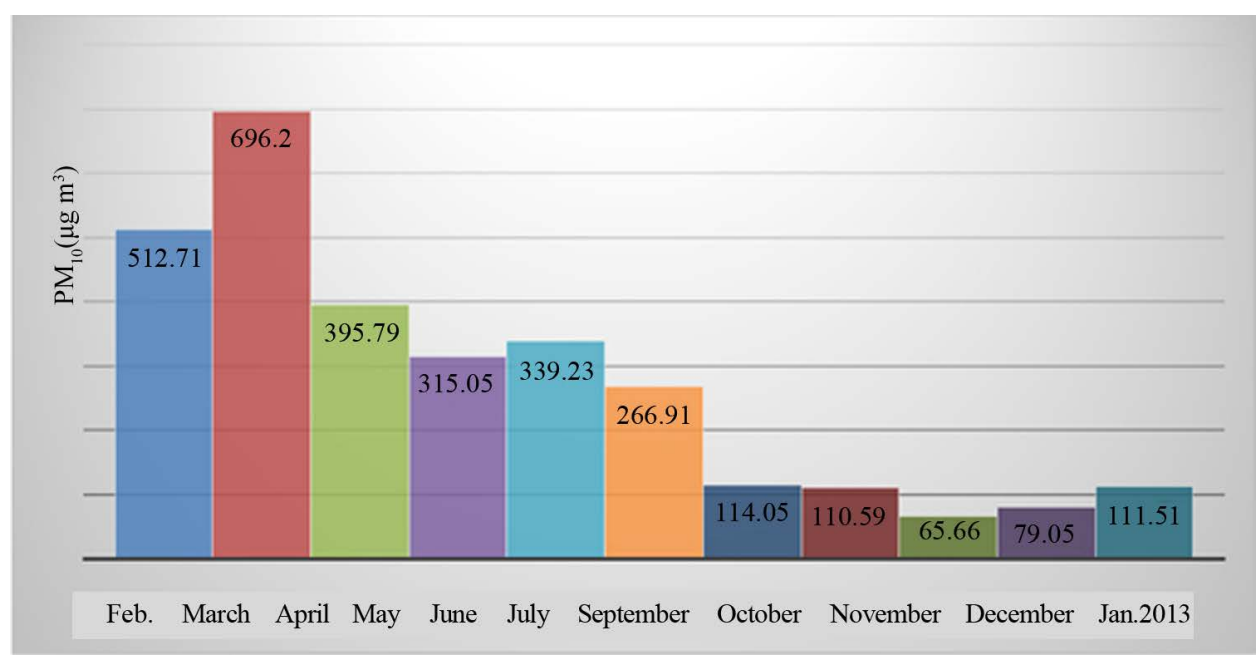

Figure 1. Average monthly $\mathrm{PM}_{10}$ mass concentration during Feb. 2012-January 2013 (A.P).

events [15]. The highest $\mathrm{PM}_{10}$ concentration $\left(2234 \mu \mathrm{g} \cdot \mathrm{m}^{-3}\right)$ is recorded during March $18^{\text {th }}$, closely associated with a severe dust event. One can, therefore, conclude that the intense dust storms taking place on specific days during spring and early summer are predominantly responsible for the large month-to month variations at all PM concentrations. The annual pattern of $\mathrm{PM}_{10}$ shows a significant increase in spring and summer where monthly mean concentrations of up to $696 \mu \mathrm{g} \cdot \mathrm{m}^{-3}$ were recorded in March. $\mathrm{PM}_{10}$ concentrations during winter months are significantly lower, with $65 \mu \mathrm{g} \cdot \mathrm{m}^{-3}$ measured in November and $79 \mu \mathrm{g} \cdot \mathrm{m}^{-3}$ measured in December. January exhibits $\mathrm{PM}_{10}$ concentrations of little above $100 \mu \mathrm{g} \cdot \mathrm{m}^{-3}$, which persists until February when $\mathrm{PM}_{10}$ levels increase as a result of dust events.

The $\mathrm{PM}_{10}$ data when grouped by month (Figure 2), indicated a consistent and systematic pattern decreasing in the order: spring (February-April, 53\%) followed by summer (May-July, 30\%) and fall and winter (SeptemberJanuary, $18 \%$ ). The spring Peak of $\mathrm{PM}_{10}$ is coinciding with dust events that commonly occur during spring in Riyadh. In contrast, the lowest PM concentration in winter can be attributed to the absence of dust events during winter. The variation of monthly mean $\mathrm{PM}_{2.5}$ (Figure 3, Figure 4) is quite similar to $\mathrm{PM}_{10}$; (March maximum). The similarity in the annual variation between $\mathrm{PM}_{10}$ and $\mathrm{PM}_{2.5}$ suggests some similarities in source regions for these aerosol sizes.

Some studies conducted in other urban environments, in Turkey [16] and in Athens, Greece [17] found, contrary to our results, that in winter both PM concentrations were higher, which was attributed to larger use of fossil fuels in winter. A monthly mean $\mathrm{PM}_{10}$ concentrations in Athens ranging from $60.3 \mu \mathrm{g} \cdot \mathrm{m}^{-3}$ (January) to 88.9 $\mu \mathrm{g} \cdot \mathrm{m}^{-3}$ (December), with an annual mean value of $75.5 \mu \mathrm{g} \cdot \mathrm{m}^{-3}$ was reported [17]. In Barcelona, Spain, the ambient $\mathrm{PM}_{10}$ and $\mathrm{PM}_{2.5}$ were in the range of 39 to $42 \mu \mathrm{g} \cdot \mathrm{m}^{-3}$ and 25 to $29 \mu \mathrm{g} \cdot \mathrm{m}^{-3}$, respectively over the period 2003-2006 with 97 daily values exceeding $50 \mu \mathrm{g} \cdot \mathrm{m}^{-3}$ [18] while the mean annual PM10 concentration ranges from 20 to $37 \mu \mathrm{g} \cdot \mathrm{m}^{-3}$ in Rio de Janeiro, Brazil [19]. Comparing the present results with those of the abovementioned studies, it is concluded that the city of Riyadh is exposed to much higher PM concentration levels. This is not only the case for summer, when the area is affected by natural phenomena, but also for winter. This highlights the fact that PM concentrations over Riyadh can be regarded as a genuine environmental problem that poses a real risk to quality of life and threatens human health.

\subsubsection{King Fahd Station (2012)}

The monthly mean values of $\mathrm{PM}_{10}, \mathrm{PM}_{2.5}$, and $\mathrm{PM}_{1}$ in 2012-2013 are shown in Figure 5-7, and the month wise percentage share of $\mathrm{PM}_{10}$ in 2012 is shown in a pie chart (Figure 8). The concentrations of $\mathrm{PM}_{10}$ are highest in summer (June-July 23\% and 24\% respectively). The concentration decreases in September and October (14\%) and reaches its minimum in November (10\%). The monthly variability of $\mathrm{PM}_{2.5}$ (Figure 9) followed the same trend except the relatively higher percentage which was registered in December (20\%). On the other hand it is noticeable that the monthly variability of $\mathrm{PM}_{1}$ (Figure 10) reflected higher percentage in winter months, (December, November and October, $21 \%, 17 \%$ and $17 \%$ respectively). The difference in the monthly variation 


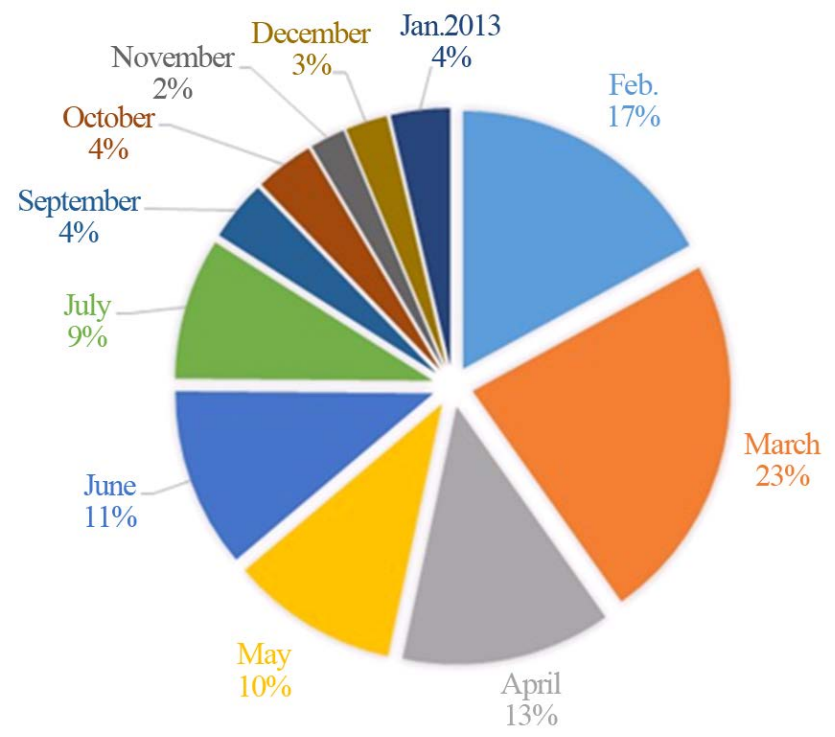

Figure 2. Monthly variation of $\mathrm{PM}_{10}$ represented as pie chart (A.P).

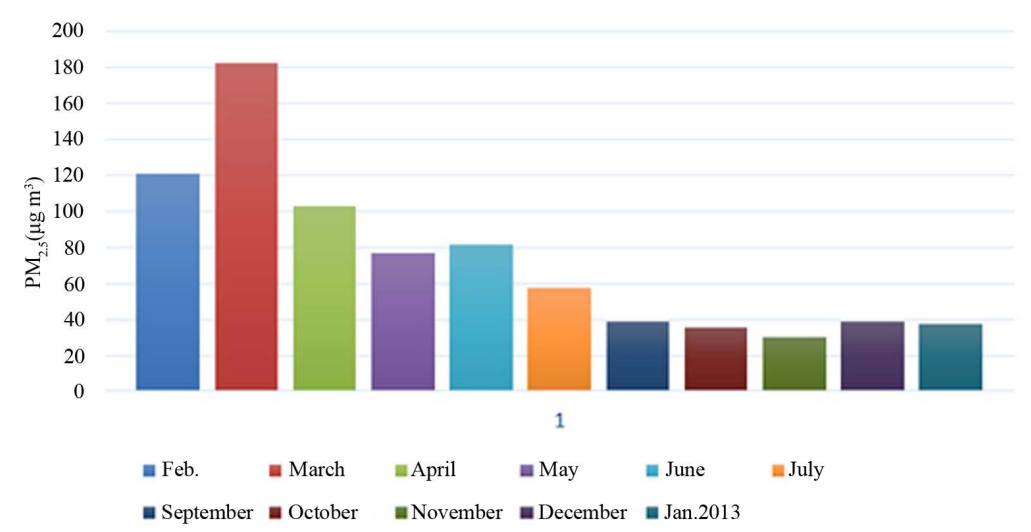

Figure 3. Average monthly $\mathrm{PM}_{2.5}$ mass concentration during Feb. 2012-January 2013 (A.P).

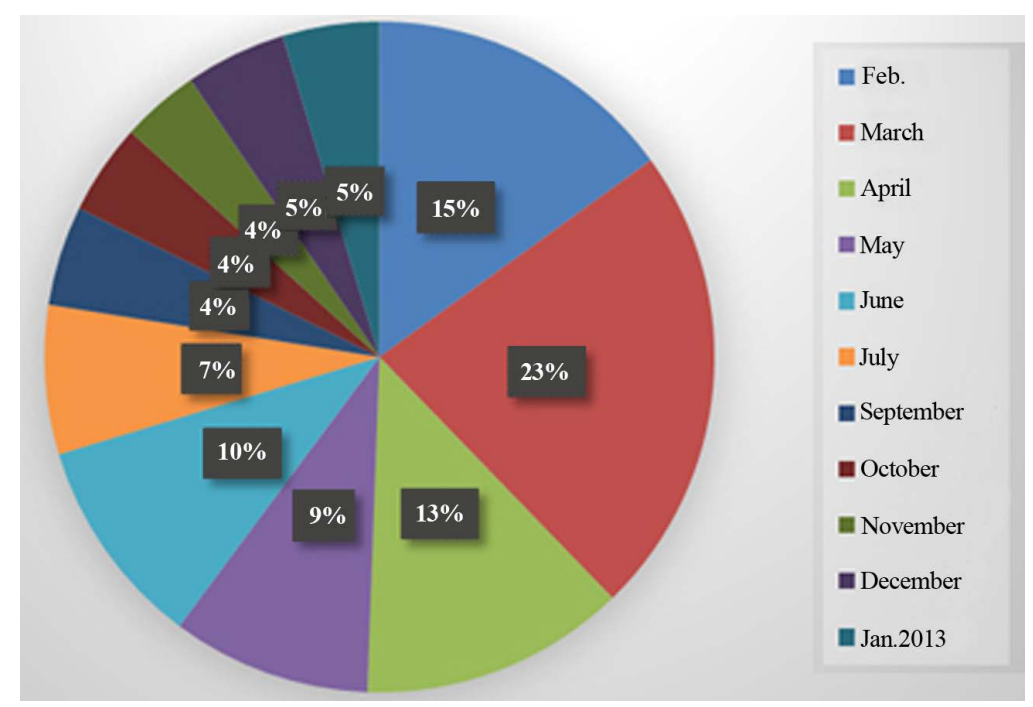

Figure 4. Monthly variation of $\mathrm{PM}_{2.5}$ represented as pie chart (A.P). 


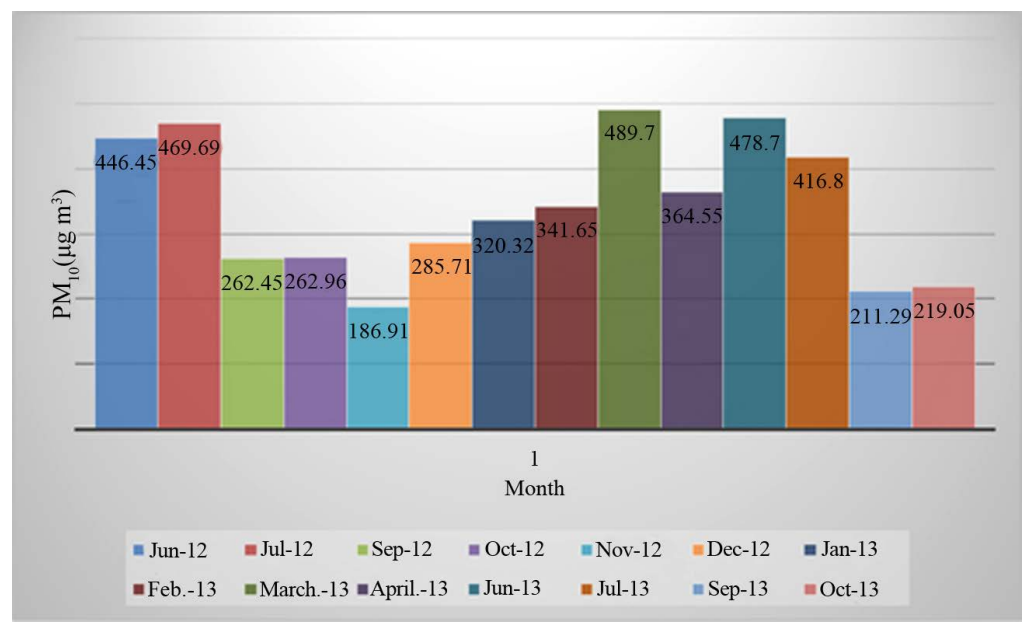

Figure 5. Average monthly (King Fahd) $\mathrm{PM}_{10}$ mass concentration during June 2012-October 2013 (A.P).

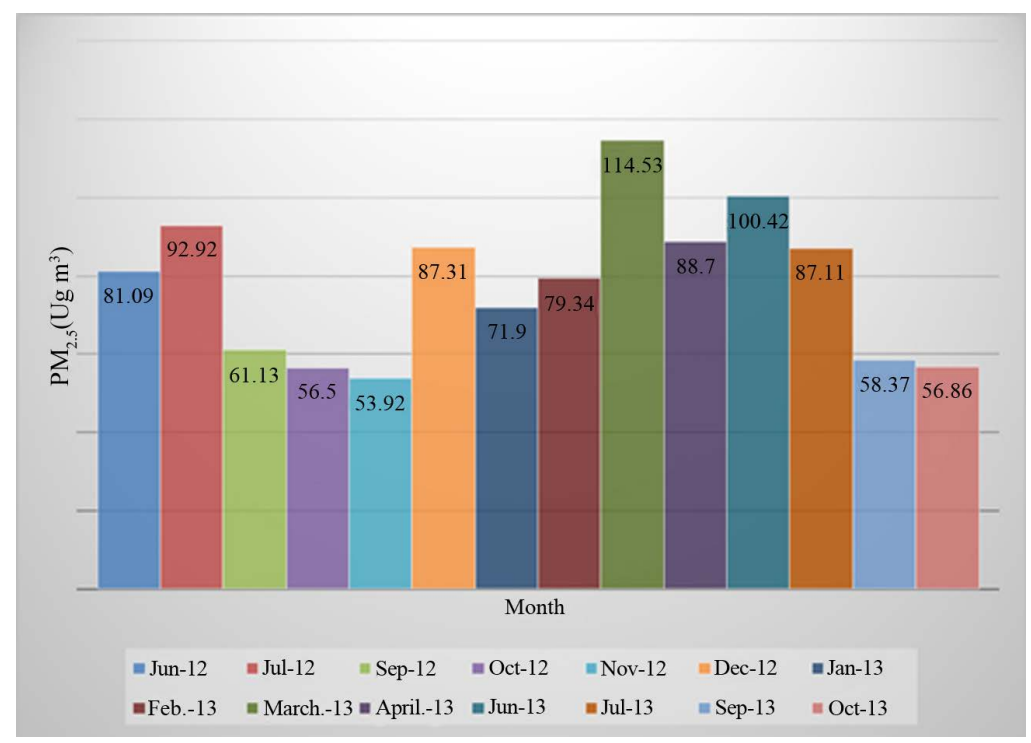

Figure 6. Average monthly (King Fahd) $\mathrm{PM}_{2.5}$ mass concentration during June 2012-October 2013.

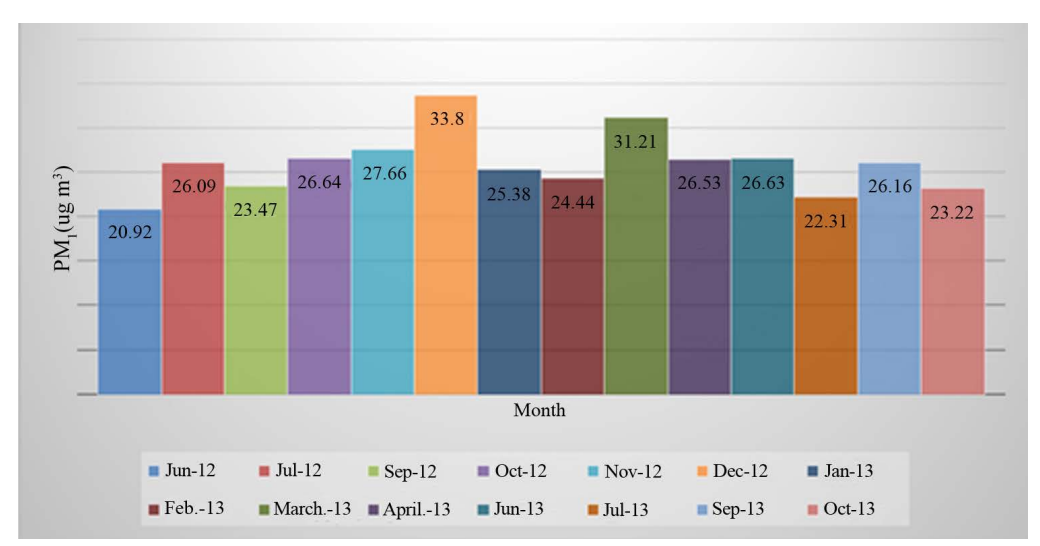

Figure 7. Average monthly (King Fahd) $\mathrm{PM}_{1}$ mass concentration during June 2012-October 2013. 


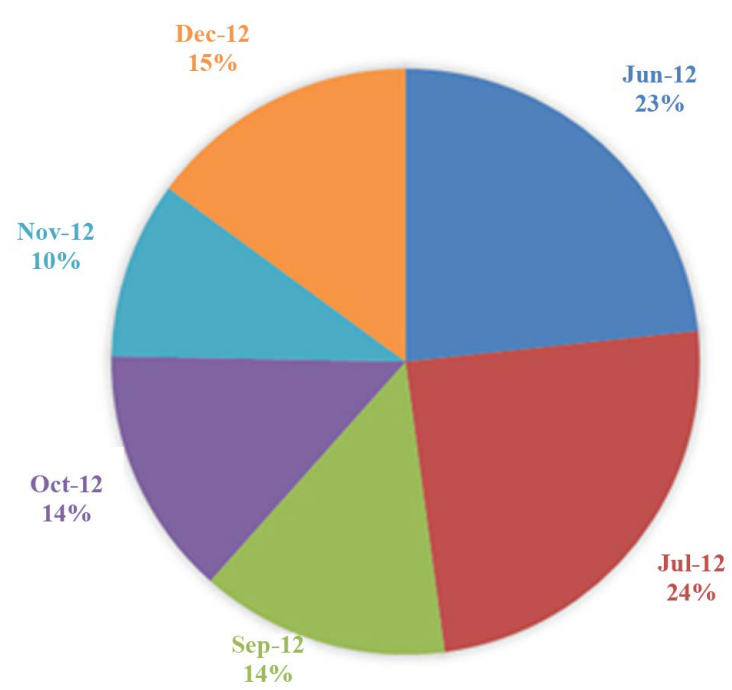

Figure 8. Monthly variation of $\mathrm{PM}_{10}$ represented as pie chart (King Fahd 2012).

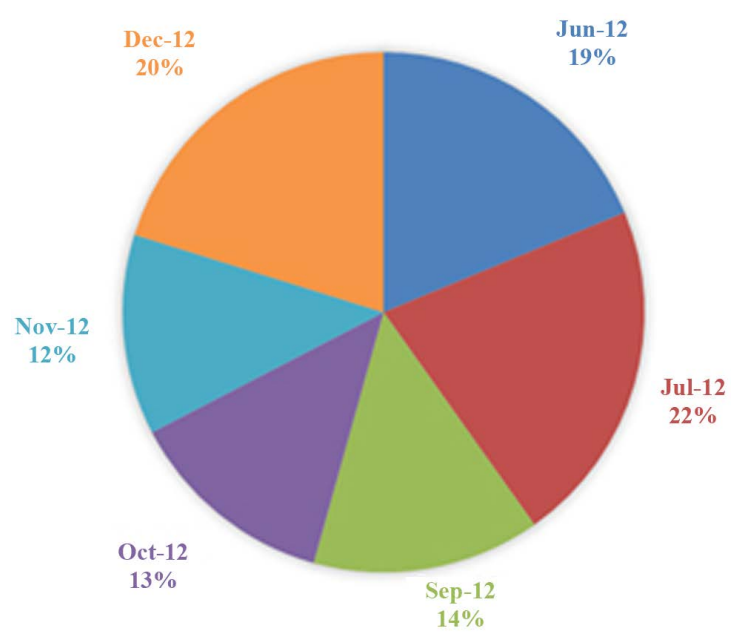

Figure 9. Monthly variation of $\mathrm{PM}_{2.5}$ represented as pie chart (King Fahd 2012).

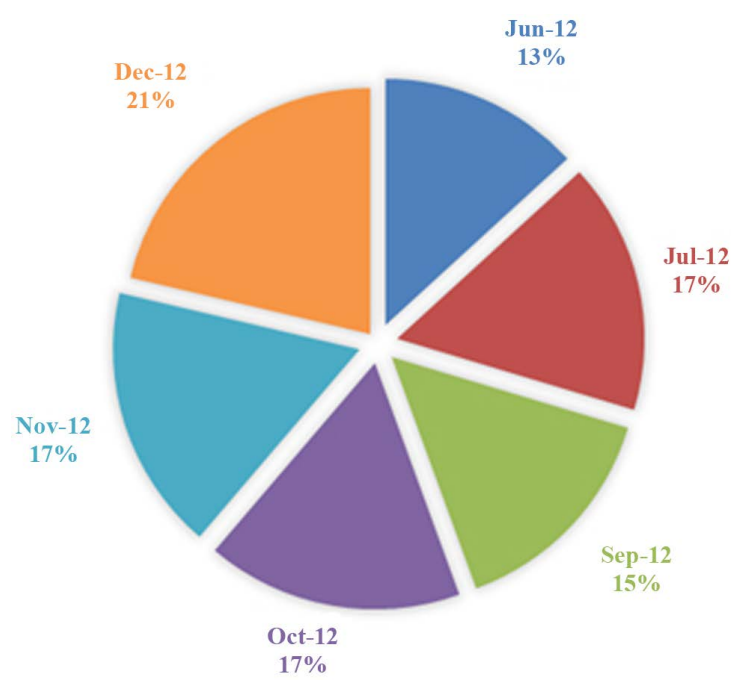

Figure 10. Monthly variation of $\mathrm{PM}_{1.0}$ represented as pie chart (King Fahd 2012). 
between $\mathrm{PM}_{10}$ on one hand and $\mathrm{PM}_{2.5}$ and $\mathrm{PM}_{1.0}$ on the other hand, may suggests differences in source regions for these aerosol sizes. The main anthropogenic source of $\mathrm{PM}_{2.5-1}$ in Riyadh urban environment can be confined to vehicular traffic, fossil-fuel combustion, been observed within urban environments in other cities [20]-[22]. In addition, the boundary layer mixing height is lower in winter and traps the pollutants near the ground as a result of temperature inversions. This may explain the relatively higher concentration of small-sized particles $\left(\mathrm{PM}_{1.0}\right)$ in winter. In contrast, during summer months thermal heating at the surface and the increase of the mixing layer height favors buoyancy and the dilution of anthropogenic aerosols $\left(\mathrm{PM}_{1.0}\right)$. Apart from desert dust, a natural contribution to the total PM (mainly to $\mathrm{PM}_{2.5}$ and $\mathrm{PM}_{10}$ ) is also expected to originate from eolian and trafficdriven re-suspension of dust, since the scarce rainfall favors the accumulation of road dust in summer.

\subsubsection{King Fahd Station (2013)}

The variation of monthly mean $\mathrm{PM}_{10}$ in 2013 showed more or less similar results to 2012 during month June, July, September and October. Higher concentrations were observed during spring and summer $(12 \%, 17 \%$ and 13\% in Feb., March and April respectively and 17, 15\% during June and July,). Starting from September and October $\mathrm{PM}_{10}$ concentrations started to drop to $7 \%$ and $8 \%$ respectively (Figure 11). Data of November and December is expected to drop further as was demonstrated in 2012 at both KF and AP stations. As described above, a characteristic seasonal variation can be observed during 2013 with relatively elevated PM concentrations observed in the warmer seasons peaking in March, June and July (Figure 11). This is consistent with the earlier results at the airport station. Higher summertime PM concentrations can be attributed to elevated wind speed that enhances wind induced re-suspended PM concentrations. Wind speeds are higher in the summer. A somewhat similar pattern—if reduced in magnitude was observed during 2012

In contrast, the variation of monthly mean $\mathrm{PM}_{2.5}$ and $\mathrm{PM}_{1}$ concentrations vary less seasonally compared to $\mathrm{PM}_{10}$ mass concentrations (Figure 12, Figure 13) This has been observed previously during 2012. This could be due to the fact that a major source for $\mathrm{PM}_{2.5}$ and $\mathrm{PM}_{1}$ which is motor-vehicle emissions is not directly affected by seasons. In contrast, secondary atmospheric formation of fine particles through photochemical processes is higher during the summer (relatively higher concentrations are observed from May-October). Stronger source strength in the summer however is counterbalanced by the lower mixing height in winter months thus reducing seasonal variability.

In general, the results of $\mathrm{PM}_{10}, \mathrm{PM}_{2.5}$, and, $\mathrm{PM}_{1}$ concentrations, obtained during the current work were little higher than those found in other studies. Results obtained by studies of $\mathrm{PM}_{2.5}$ concentrations conducted in China [23] reported a mean $\mathrm{PM}_{2.5}$ concentration of $67.6 \mu \mathrm{g} / \mathrm{m}^{3}$. Also [24] reported $89 \mu \mathrm{g} / \mathrm{m}^{3}$ during the spring. These values are little less than the values reported in this study. On the other hand, some other studies reported more or less similar results. For an example, $\mathrm{PM}_{10}$ concentrations higher than 3000 and produced by dust events were

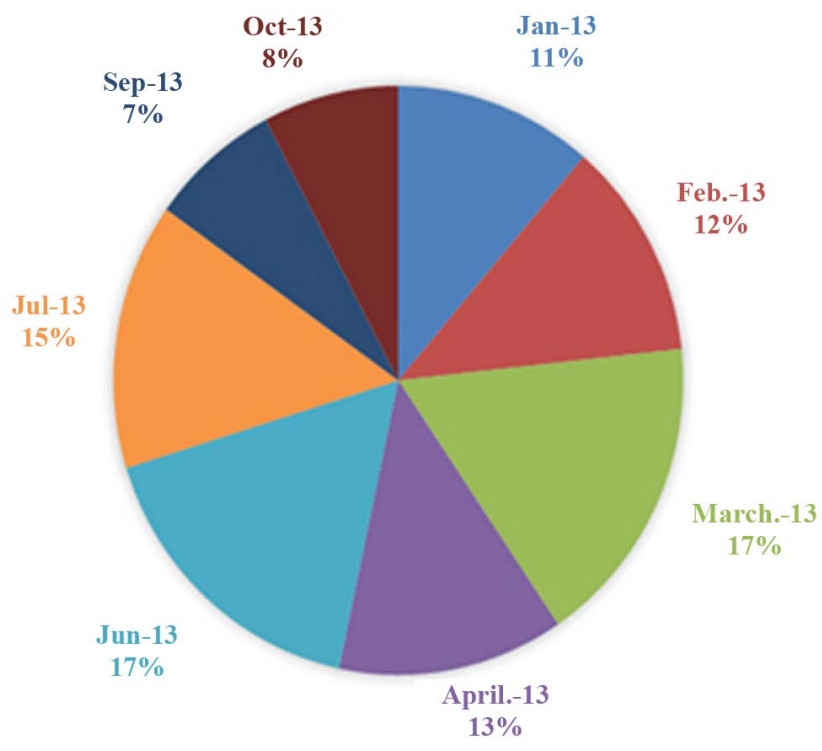

Figure 11. Monthly variation of $\mathrm{PM}_{10}$ represented as pie chart (King Fahd 2013). 


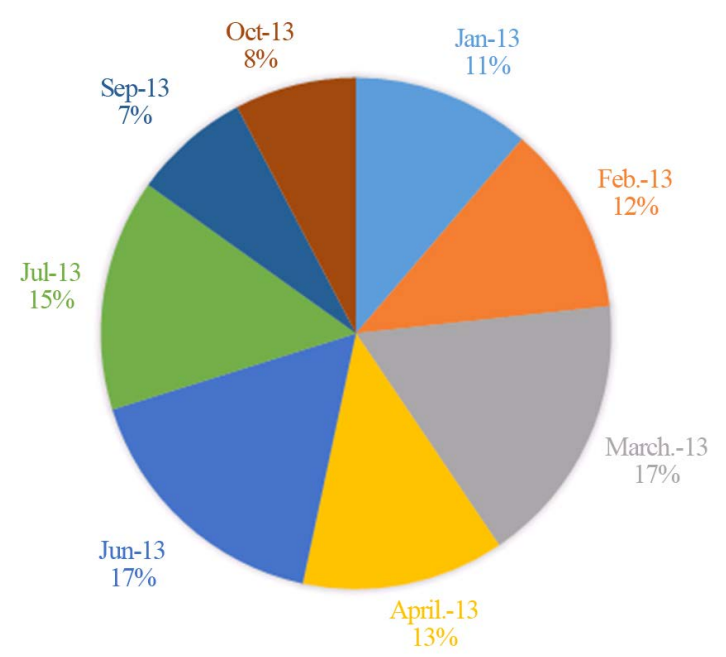

Figure 12. Monthly variation of $\mathrm{PM}_{2.5}$ represented as pie chart (King Fahd 2013).

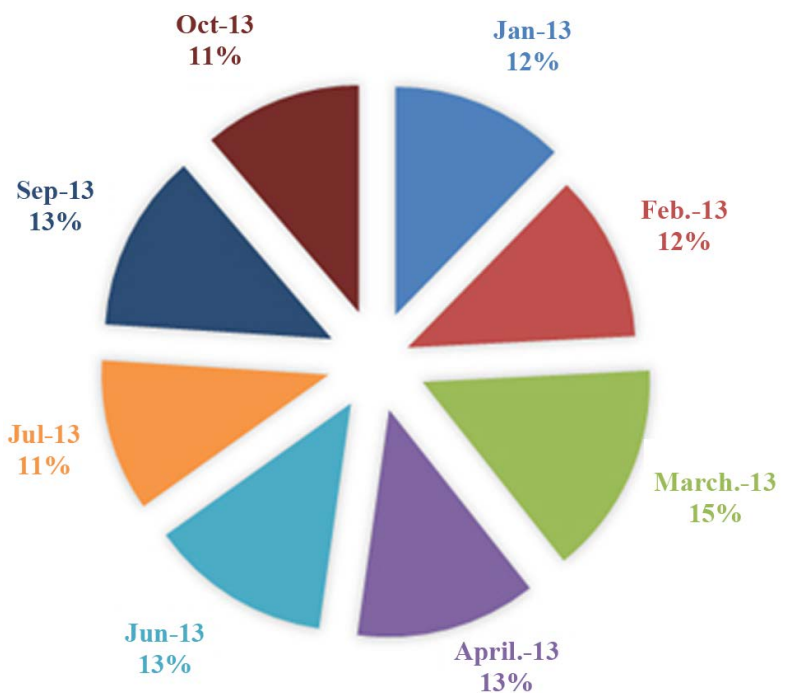

Figure 13. Monthly variation of $\mathrm{PM}_{1.0}$ represented as pie chart (King Fahd 2013).

observed in a study conducted in Iraq, Kuwait and Saudi Arabia [25]. In contrast, Meng and Lu [26] observed mean $\mathrm{PM}_{2.5}$ concentrations of up to $216.7 \mu \mathrm{g} / \mathrm{m}^{3}$, which was higher than the results presented in this study (almost double). The explanation for this substantial difference is that the $\mathrm{PM}_{2.5}$ is measured during winter months where fossil fuel combustions which considered as the primary source of fine particulate are highest.

\subsection{Frequency Distribution of $\mathrm{PM}_{10}$ and $\mathrm{PM}_{2.5}$ Concentrations}

\subsubsection{Airport}

The frequency of occurrence for $\mathrm{PM}_{10}$ and $\mathrm{PM}_{2.5}$ concentrations for the studied period in A.P station showed that $4.5 \%$ of the PM10 values were more than $1000 \mu \mathrm{g} \cdot \mathrm{m}^{-3}$ occurring all in spring. Approximately $9.5 \%, 9 \%$ and $16 \%$ occurred at $500-1000,340-500$ and $200-340 \mu \mathrm{g} \cdot \mathrm{m}^{-3}$ interval, respectively. A peak in the distribution of $\mathrm{PM}_{10}$ concentrations occurred at $100-200 \mu \mathrm{g} \cdot \mathrm{m}^{-3}$, (32\%). The percentage of occurrence of values $50-100 \mu \mathrm{g} \cdot \mathrm{m}^{-3}$ and less than $50 \mu \mathrm{g} \cdot \mathrm{m}^{-3}$ were $19 \%$ and $9 \%$ respectively. $\mathrm{PM}_{10}$ values $<50 \mu \mathrm{g} \cdot \mathrm{m}^{-3}$ is observed in winter months (Table 1, Table 2).

Regarding the frequency distributions of $\mathrm{PM}_{2.5}$ in all seasons the largest frequency is observed for values between 35 and $100 \mu \mathrm{g} \cdot \mathrm{m}^{-3},(52 \%)$, while in spring the largest frequency shifts towards higher values $(100-600$ $\mu \mathrm{g} \cdot \mathrm{m}^{-3}, 18 \%$. Similarly to PM10, spring presents a broader distribution for $\mathrm{PM}_{2.5}$, with values $>100 \mu \mathrm{g} \cdot \mathrm{m}^{-3}$ 
Table 1. Frequency of occurrence of $\mathrm{PM}_{10}$ concentrations (King Fahad).

\begin{tabular}{|c|c|c|}
\hline Season & $\mathbf{P M}_{10}$ concentration & \% Frequency \\
\hline \multirow{5}{*}{ June-September 2012} & $>1000$ & 2 \\
\hline & $500-1000$ & 23 \\
\hline & $340-500$ & 19 \\
\hline & $180-340$ & 55 \\
\hline & $<180$ & 0 \\
\hline \multirow{6}{*}{ October-January } & $>1000$ & 1 \\
\hline & $500-1000$ & 5 \\
\hline & $340-500$ & 15 \\
\hline & $200-340$ & 40 \\
\hline & $100-200$ & 31 \\
\hline & $50-100$ & 7 \\
\hline \multirow{6}{*}{ Feb-March } & $>1000$ & 5 \\
\hline & $500-1000$ & 17 \\
\hline & $340-500$ & 18.5 \\
\hline & $200-340$ & 47.5 \\
\hline & $100-200$ & 12 \\
\hline & $50-100$ & 0 \\
\hline \multirow{5}{*}{ June-October } & $>1000$ & 3 \\
\hline & $500-1000$ & 12 \\
\hline & $340-500$ & 11 \\
\hline & $200-340$ & 30 \\
\hline & $100-200$ & 43 \\
\hline
\end{tabular}

Table 2. Frequency of occurrence of $\mathrm{PM}_{2.5}$ concentrations (King Fahad).

\begin{tabular}{ccc}
\hline Season & PM $_{\mathbf{1 0}}$ concentration & \% Frequency \\
\hline June-September 2012 & $>100$ & 27 \\
& $50-100$ & 50 \\
Less than 50 & 23 \\
More 500 & 1.5 \\
$200-500$ & 3 \\
October-January & $100-200$ & 6 \\
& $50-100$ & 57.5 \\
Feb-March & Less than 50 & 33 \\
& More 200 & 8.5 \\
& $100-200$ & 18.5 \\
& $50-100$ & 46 \\
June-October & Less than 50 & 27 \\
& More 200 & 4 \\
& $100-200$ & 16 \\
& $50-100$ & 37 \\
\hline
\end{tabular}


range. Apart from these similarities in the $\mathrm{PM}_{10}$ and $\mathrm{PM}_{2.5}$ frequency distributions, some differences in winter and summer reveal a possible different source of aerosols in these seasons (natural or anthropogenic). For example, the intense dust storms during summer do not have such a pronounced signal in $\mathrm{PM}_{2.5}$ concentrations as in $\mathrm{PM}_{10}$ ones, while the larger contribution of anthropogenic aerosols in winter rather increases the $\mathrm{PM}_{2.5}$ levels. However, it should be noted that dust events may also affect significantly the $\mathrm{PM}_{2.5}$ levels, as observed during a severe dusty day in March.

\subsubsection{King Fahd}

The frequency of occurrence for $\mathrm{PM}_{10}$ and $\mathrm{PM}_{2.5}$ concentrations for each season is depicted in table, respectively. In summer 2012 (June-September), 55\% of the $\mathrm{PM}_{10}$ values were between 180 and $340 \mu \mathrm{g} \cdot \mathrm{m}^{-3} ; 25 \%$ of the $\mathrm{PM}_{10}$ values were more than $500 \mu \mathrm{g} \cdot \mathrm{m}^{-3}$. In October 2012 to January 2013, the frequency distribution shifts towards lower values, with values above $500 \mu \mathrm{g} \cdot \mathrm{m}^{-3}$ only $6 \%$ and the peak frequency occurred for values between 200 $340 \mu \mathrm{g} \cdot \mathrm{m}^{-3}$ (40\%). On the other hand, a considerable fraction (24\%) of $\mathrm{PM}_{10}$ values $<500 \mu \mathrm{g} \cdot \mathrm{m}^{-3}$ is observed in spring (Feb.-March). The frequency of occurrence for PM10 during June to October is some who resembles the values of the summer months. Peak concentrations occurred for values between $100-200 \mu \mathrm{g} \cdot \mathrm{m}^{-3}$ (43\%), 15\% of the values were above $500 \mu \mathrm{g} \cdot \mathrm{m}^{-3}$. Regarding the frequency distributions of $\mathrm{PM}_{2.5}$ in all seasons except JuneOctober, the largest frequency is observed for values between 50 and $100 \mu \mathrm{g} \cdot \mathrm{m}^{-3}$, while in June-October the largest frequency shifts towards lower values $\left(<50 \mu \mathrm{g} \cdot \mathrm{m}^{-3}\right)$, which is opposite to that observed for $\mathrm{PM}_{10}$. However, similarly to $\mathrm{PM}_{10}$, summer presents a broader distribution for $\mathrm{PM}_{2.5}$, with values $>$ a $100 \mu \mathrm{g} \cdot \mathrm{m}^{-3}$ range. Apart from these similarities in the $\mathrm{PM}_{10}$ and $\mathrm{PM}_{2.5}$ frequency distributions, some differences in winter and summer reveal a possible different source of aerosols in these seasons (natural or anthropogenic). For example, the intense dust storms during summer do not have such a pronounced signal in $\mathrm{PM}_{2.5}$ concentrations as in $\mathrm{PM}_{10}$ ones, while the larger contribution of anthropogenic aerosols in winter rather increases the $\mathrm{PM}_{2.5}$ levels. Also note that the mean $\mathrm{PM}_{2.5}$ in winter $\left(32 \mu \mathrm{g} \cdot \mathrm{m}^{-3}\right)$ is similar to that of spring and larger than that of autumn, despite the fact that winter $\mathrm{PM}_{10}$ is the lowest. However, it should be noted that dust events may also affect significantly the $\mathrm{PM}_{2.5}$ levels, as observed during a severe dusty day in June $\left(\mathrm{PM}_{2.5}\right.$ daily value of $\left.182 \mu \mathrm{g} \cdot \mathrm{m}^{-3}\right)$ (Table 1, Table 2).

During this study period, we observed that $\mathrm{PM}_{10}$ and $\mathrm{PM}_{2.5}$ concentrations mainly depend on dust storms occasions and increased significantly during dust storms; however, there is no universally accepted definition of dust storms in terms of hourly dust concentrations. Previous researchers have classified dust storms by their intensities on the basis of hourly mean $\mathrm{PM}_{10}$ concentrations together with wind speed and visibility. The classification system proposed by Hoffmann et al., [27] is based on the hourly mean $\mathrm{PM}_{10}$ concentration in combination with visibility and wind speed as follows: "dusty air" (haze) means hourly mean $\mathrm{PM}_{10}$ concentrations higher than $50 \mu \mathrm{g} \cdot \mathrm{m}^{-3}$; "light dust storm", $>200 \mu \mathrm{g} \cdot \mathrm{m}^{-3}$; "dust storm", $>500 \mu \mathrm{g} \cdot \mathrm{m}^{-3}$; "strong dust storm", $>2000 \mu \mathrm{g} \cdot \mathrm{m}^{-3}$; and "serious strong dust storm", $>5000 \mu \mathrm{g} \cdot \mathrm{m}^{-3}$. Wang et al. [28] used hourly mean $\mathrm{PM}_{10}$ concentrations of $<200$ $\mu \mathrm{g} \cdot \mathrm{m}^{-3}$ for "suspended dust," $200-5500 \mu \mathrm{g} \cdot \mathrm{m}^{-3}$ for "blowing dust," $5500-15,000 \mu \mathrm{g}^{-3}$ for "sand and dust storm", and $>15,000 \mu^{-3}$ for "severe sand and dust storm".

In Taiwan an Asian dust storm event is defined each day that hourly mean $\mathrm{PM}_{10}$ concentrations observed at the Yangmingshan station exceed the air quality standard $\left(125 \mu \mathrm{g} \cdot \mathrm{m}^{-3}\right)$ for a period of at least $3 \mathrm{~h}$ [29]. Dust storms are defined in Korea when the measured $\mathrm{PM}_{10}$ concentration exceeds $190 \mu \mathrm{g} \cdot \mathrm{m}^{-3}$ for at least $2 \mathrm{~h}$ [30]. The KMA has developed an Asian Dust Warning System with alarm, advisory, and warning levels depending on the dust concentration. Alarms, advisories, and warnings are issued when the hourly mean dust concentrations $\left(\mathrm{PM}_{10}\right)$ are expected to exceed $300 \mu \mathrm{g} \cdot \mathrm{m}^{-3}, 400 \mu \mathrm{g} \cdot \mathrm{m}^{-3}$, or $800 \mu \mathrm{g} \cdot \mathrm{m}^{-3}$, respectively, for over $2 \mathrm{~h}$ [30]. Park et al. (2010) [31] identified dust events as the peak PM10 concentration exceeding one standard deviation of the annual mean concentration. We arbitrary choose this criterion. Our criterion for dust storm events was an hourly mean $\mathrm{PM}_{10}$ concentration exceeding one standard deviation of the mean concentration at the airport station during February 2012 to January 2013 months (mean $=282.11 .34 \mu \mathrm{g} / \mathrm{m}^{3}$ and standard deviation $=372$ ). Based on this criterion, we identified 16, 21, 10, 6, 5, 6 and 1 dust events at February, March, April, May, June, July and December 2013. Based on the same criterion, we identified 8, 17, 7, 7, 3, and 6 dust events at June, July, September, October, November and December 2012 and 14, 11, 20, 16, 7, 9, and 4 at January, February, March, June, July September and October 2013 respectively.

\subsection{Influence of Meteorological Parameters on Particulate Matter}

Air quality strongly depends on the dynamics of the atmosphere and meteorological conditions play a vital role 
in governing the fate of air pollutants. During the monitoring period in the AP station, the hottest day of 2012 was July 17 , with a high temperature of $47^{\circ} \mathrm{C}$. The longest warm spell was from July 14 to August 5, constituting 23 consecutive days with warmer than average high temperatures. The month of May had the largest fraction of warmer than average days with $84 \%$ days with higher than average high temperatures.

The highest sustained wind speed was $15 \mathrm{~m} / \mathrm{s}$, occurring on February 2; the highest daily mean wind speed was $10 \mathrm{~m} / \mathrm{s}$ (June 3); and the highest wind gust speed was $23 \mathrm{~m} / \mathrm{s}$ (February 25). The windiest month was May, with an average wind speed of $4 \mathrm{~m} / \mathrm{s}$. The least windy month was October, with an average wind speed of $2 \mathrm{~m} / \mathrm{s}$.

The average daily temperature in KF was found to be very similar to that of the AP. The relative humidity had also rather a low spatial variability (Correlation coefficients for temperature and relative humidity for these two sites was $r=0.899$ and 0.974 respectively

The relationships between the mean values of suspended particle concentrations and meteorological variables (relative humidity and ambient temperature for these two locations and wind speed, temperature and relative humidity for KF station, were analyzed using Pearson's correlation analysis, the analyses results are represented in Table 3 for the AP and Table 4 for KF.

The results indicated that, the $\mathrm{PM}_{10}$ and $\mathrm{PM}_{2.5}$ were strongly correlated with each other and inversely correlated with temperature and relative humidity with correlation coefficient of -0.11 and -0.15 respectively at the AP station. The resulting t-value is not statistically significant at the 0.05 level. This may be due to the fact that means of the whole day of PM on one hand and the average temperature humidity on the other hand might cancel the variation between night and day. In this regard, Shao [32], stated that the influence of weather factors upon repairable dust particulates is largely inconclusive. Never the less, several studies have confirmed the influence of meteorological conditions on PM concentrations [33] [34]. Atmospheric pressure, wind velocity temperature and humidity were found to be significant factors in influencing PM.

On the other hand, at KF station a moderate positive correlation was observed between wind speed and PM $(\mathrm{r}=$ 0.48, 0.45 and 0.38 for $\mathrm{PM}_{10}, \mathrm{PM}_{2.5}$, and $\mathrm{PM}_{1}$ respectively) due to their suspension effect of wind. The best correlation was observed with wind speeds and $\mathrm{PM}_{10}(\mathrm{r}=0.48)$. It seems that the wind has the potential to transport particulates between areas around the studied site. Contrary to our results Oren [35], found that wind speed yielded negative correlation with $\mathrm{PM}_{10}$ but positive and statistically significant at 0.01 confidence level with $\mathrm{PM}_{2.5-10}$. Wind speed plays a leading role in cleansing atmosphere of fine particulates compare to course. Wind speed affects the turbulence near the ground. The greater the wind speed, the greater the dispersion of particulates, the greater the dilution effects and transport of the particulate hence the lower the mass concentration [36].

Table 3. Correlation coefficient of particulate data and meteorological factors AP station.

\begin{tabular}{cccccc} 
& PM $_{10}$ & PM $_{2.5}$ & TEMP & RH & Dew point \\
\hline PM $_{10}$ & 1.000 & & & & \\
PM $_{2.5}$ & $0.986^{* *}$ & 1.00 & & & \\
TEMP & -0.108 & -0.105 & 1.00 & & \\
RH & -0.147 & -0.090 & -0.708 & 1.00 & \\
Dew point & -0.398 & -0.338 & 0.082 & 0.6454 & 1.00 \\
\hline
\end{tabular}

** Highly significant.

Table 4. Correlation coefficient of particulate data and meteorological factors KF station.

\begin{tabular}{cccccccc}
\hline & $\mathbf{P M}_{\mathbf{1 0}}$ & $\mathbf{P M}_{\mathbf{2 . 5}}$ & $\mathbf{P M}_{\mathbf{1}}$ & TEMP & $\mathbf{R H}$ & Wind speed & Dew point \\
\hline $\mathrm{PM}_{10}$ & 1.000 & & & & & & \\
$\mathrm{PM}_{2.5}$ & 0.967 & 1.00 & & & & & \\
$\mathrm{PM}_{1}$ & 0.792 & 0.871 & 1.00 & & & & \\
TEMP & 0.074 & -0.009 & -0.0922 & 1.00 & & & \\
RH & -0.127 & -0.090 & 0.203 & -0.772 & 1.00 & & \\
Wind speed & 0.479 & 0.453 & 0.380 & 0.182 & -0.107 & 1.00 & \\
Dew point & -0.147 & -0.334 & 0.222 & -0.101 & 0.6454 & -0.0306 & 1.00 \\
\hline
\end{tabular}




\subsection{Spatial Variations of $\mathrm{PM}_{10}$ and $\mathrm{PM}_{2.5}$}

Figure 14 shows the average concentrations of $\mathrm{PM}_{10}$ and $\mathrm{PM}_{2.5}$ at these two monitoring stations during the study period. Both $\mathrm{PM}_{10}$ and $\mathrm{PM}_{2.5}$ showed substantial variations. In the urban station (King Fahd) average annual $\mathrm{PM}_{10}$ varied by up to roughly a factor of two. This variation imply that local emission sources often contribute much (i.e. greater than half) of the $\mathrm{PM}_{10}$ mass on annual average. This may be attributed to the strengths of the related anthropogenic sources, as reflected by population size and traffic density. The observation of high $\mathrm{PM}_{10}$ levels in highly trafficked areas has been reported extensively. Based on the measurements at six locations of Kathmandu Valley, Nepal, Aryal et al. [37] reported that the mean $\mathrm{PM}_{10}$ values varied considerably from 42 (rural area) to $230 \mu \mathrm{g} / \mathrm{m}^{3}$ (urban roadside).

Similarly, based on the study from Seoul, Korea, Bae et al., [38] reported enhanced levels of $\mathrm{PM}_{10}$ in roadside (URS) over urban background (U-BG), despite similarity in relative diurnal patterns at each site. Likewise, [39] also reported enhanced (24.5\%) levels of $\mathrm{PM}_{10}$ at roadside relative to background site in Seoul which is explained by the direct effect and proximity of vehicular sources [40].

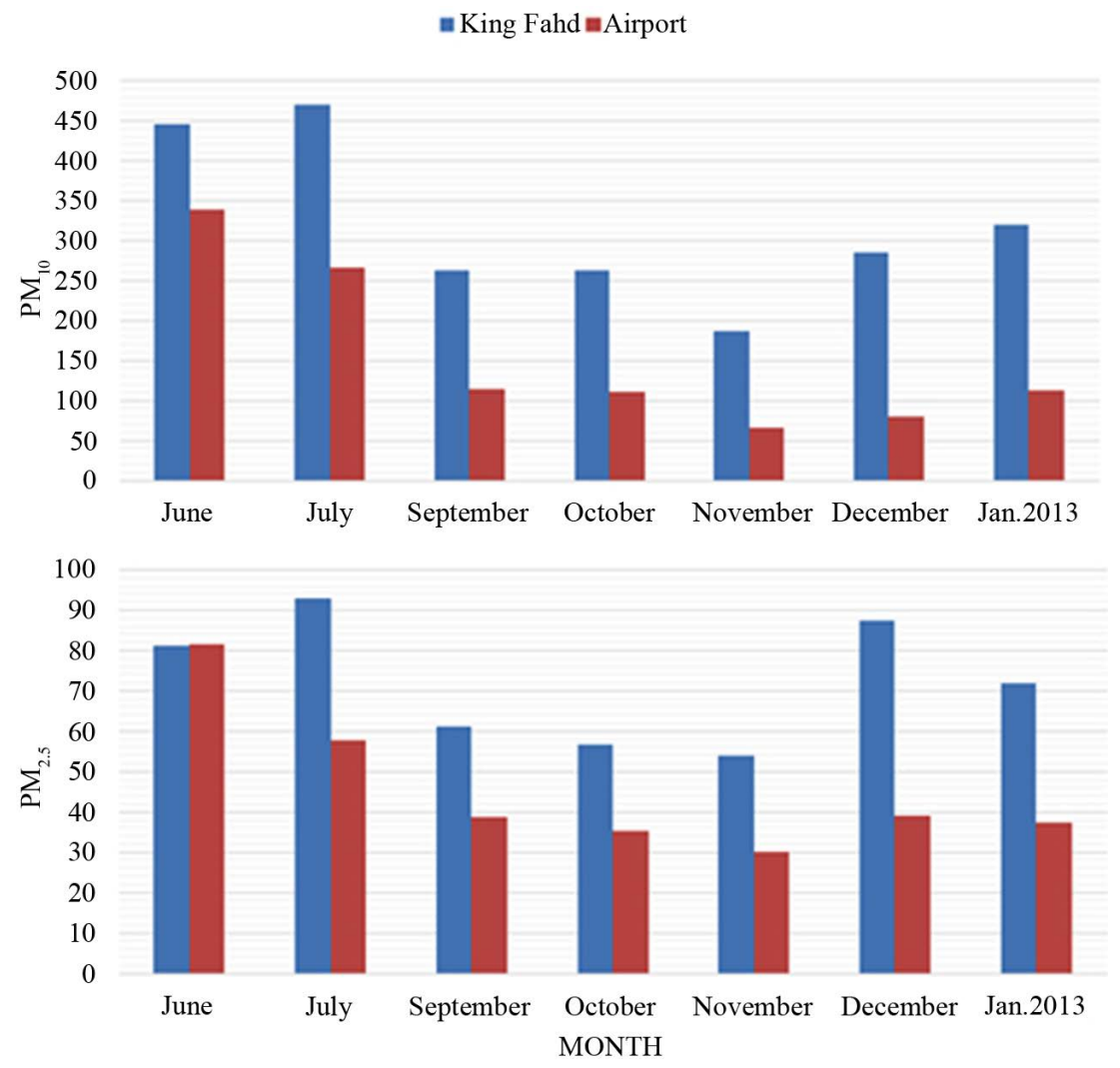

Figure 14. Concentrations of $\mathrm{PM}_{10}$ and $\mathrm{PM}_{2.5}$ at these two monitoring stations.

\section{Conclusions}

This study provides a valuable and complementary baseline data on PM. It is the first of its kind in which such data are collected in Riyadh city. However, Readers should be cautioned that the data presented in this report represent only one year of data (twelve months), and that patterns may vary and may not be conclusive at this stage. Since many studies have demonstrated a close relationship between particulate matter (PM) pollution and deterioration in human health, as such, there is a need for constantly monitoring the air quality and PM concentrations throughout Riyadh city to find out if different areas meet national ambient air quality standards. These standards require to be reviewed every 5 years to make sure the standards protect human health and the environment. The standards must protect groups of people who are most at risk from the pollution.

The following conclusions were reached: 
1) The results show that the PM concentrations are considerably higher than the corresponding European Union air quality annual standard.

2) $\mathrm{PM}_{2.5}$ data appear to be a constant fraction of the $\mathrm{PM}_{10}$ at all the sites, indicating common influences of meteorology and sources.

3) Statistical analysis of air quality data shows that $\mathrm{PM}_{10}$ and $\mathrm{PM}_{2.5}$ are showing poor correlation with temperature and relative humidity. Wind speed is moderately correlated with PM.

4) There are clear associations between $\mathrm{PM}_{10}$ and $\mathrm{PM}_{2.5}$ data sets throughout the study period.

\section{Acknowledgements}

This study was funded by the National Plan for Science, Technology and Innovation (MAARIFAH), King Abdulaziz City for Science and Technology, Kingdom of Saudi Arabia, Project \#8 ENV319-02 under the title "Characteristics and Composition of the Falling Dust and Particulate Matter and Its Health Hazards in Riyadh City, Saudi Arabia”.

\section{References}

[1] EPA, D. (2009) Integrated Science Assessment for Particulate Matter. US Environmental Protection Agency, Washington DC.

[2] Organization, W.H. (2004) International Statistical Classification of Diseases and Related Health Problems. World Health Organization, Geneva.

[3] Barry, R.G. and Chorley, R.J. (1992) Atmosphere, Weather, and Climate. 6th Edition, CUP Archive.

[4] Sudheer, A. and Rengarajan, R. (2012) Atmospheric Mineral Dust and Trace Metals over Urban Environment in Western India during Winter. Aerosol and Air Quality Research, 12, 923-933. http://dx.doi.org/10.4209/aaqr.2011.12.0237

[5] Al-Jeelani, H. (2009) Evaluation of Air Quality in the Holy Makkah during Hajj Season 1425 H. Journal of Applied Sciences Research, 115-121.

[6] Othman, N., Jafri, M.Z.M. and San, L.H. (2010) Estimating Particulate Matter Concentration over Arid Region Using Satellite Remote Sensing: A Case Study in Makkah, Saudi Arabia. Modern Applied Science, 4, 131. http://dx.doi.org/10.5539/mas.v4n11p131

[7] Habeebullah, M. (2013) An Investigation of the Effects of Meteorology on Air Pollution in Makkah. Assiut University bulletins Environmental Researches, 16, 64-85.

[8] Munir, S., Habeebullah, T.M., Seroji, A.R., Morsy, E.A., Mohammed, A.M., Saud, W.A., Abdou, A.E. and Awad, A.H. (2013) Modeling Particulate Matter Concentrations in Makkah, Applying a Statistical Modeling Approach. Aerosol and Air Quality Research, 13, 901-910. http://dx.doi.org/10.4209/aaqr.2012.11.0314

[9] El-Shobokshy, M.S. (1984) A Preliminary Analysis of the Inhalable Particulate Lead in the Ambient Atmosphere of the City of Riyadh, Saudi Arabia. Atmospheric Environment, 18, 2125-2130. http://dx.doi.org/10.1016/0004-6981(84)90198-7

[10] El-Shobokshy, M. (1985) Atmospheric Lead Pollution in Area of Children's School in the City of Riyadh. Proceedings of 78th APCA Annual Meeting, Detroit, 16-21 June 1985, Cobo Hall·Detroit APCA'85.

[11] El-Shobokshy, M., Al-Tamrah, S. and Hussein, F. (1990) Inhalable Particulates and Meteorological Characteristics of the City of Riyadh, Saudi Arabia. Atmospheric Environment, Part B: Urban Atmosphere, 24, 261-265. http://dx.doi.org/10.1016/0957-1272(90)90031-O

[12] Rushdi, A.I., Al-Mutlaq, K.F., Al-Otaibi, M., El-Mubarak, A.H. and Simoneit, B.R. (2013) Air Quality and Elemental Enrichment Factors of Aerosol Particulate Matter in Riyadh City, Saudi Arabia. Arabian Journal of Geosciences, 6, 585-599. http://dx.doi.org/10.1007/s12517-011-0357-9

[13] Alharbi, B., Shareef, M.M. and Husain, T. (2015) Study of Chemical Characteristics of Particulate Matter Concentrations in Riyadh, Saudi Arabia. Atmospheric Pollution Research, 6, 88-98. http://dx.doi.org/10.5094/APR.2015.011

[14] Burkart, J., Steiner, G., Reischl, G., Moshammer, H., Neuberger, M. and Hitzenberger, R. (2010) Characterizing the Performance of Two Optical Particle Counters (Grimm OPC1.108 and OPC1.109) under Urban Aerosol Conditions. Journal of Aerosol Science, 41, 953-962. http://dx.doi.org/10.1016/j.jaerosci.2010.07.007

[15] Notaro, M., Alkolibi, F., Fadda, E. and Bakhrjy, F. (2013) Trajectory Analysis of Saudi Arabian Dust Storms. Journal of Geophysical Research: Atmospheres, 118, 6028-6043. http://dx.doi.org/10.1002/jgrd.50346

[16] Akyüz, M. and Çabuk, H. (2009) Meteorological Variations of $\mathrm{PM}_{2.5} / \mathrm{PM}_{10}$ Concentrations and Particle-Associated Polycyclic Aromatic Hydrocarbons in the Atmospheric Environment of Zonguldak, Turkey. Journal of Hazardous 
Materials, 170, 13-21. http://dx.doi.org/10.1016/j.jhazmat.2009.05.029

[17] Chaloulakou, A., Kassomenos, P., Spyrellis, N., Demokritou, P. and Koutrakis, P. (2003) Measurements of PM M $_{10}$ and $\mathrm{PM}_{2.5}$ Particle Concentrations in Athens, Greece. Atmospheric Environment, 37, 649-660. http://dx.doi.org/10.1016/S1352-2310(02)00898-1

[18] Pérez, N., Pey, J., Querol, X., Alastuey, A., López, J. and Viana, M. (2008) Partitioning of Major and Trace Components in $\mathrm{PM}_{10}-\mathrm{PM}_{2.5}-\mathrm{PM}_{1}$ at an Urban Site in Southern Europe. Atmospheric Environment, 42, 1677-1691. http://dx.doi.org/10.1016/j.atmosenv.2007.11.034

[19] Godoy, M.L.D., Godoy, J.M., Roldao, L.A., Soluri, D.S. and Donagemma, R.A. (2009) Coarse and Fine Aerosol Source Apportionment in Rio de Janeiro, Brazil. Atmospheric Environment, 43, 2366-2374. http://dx.doi.org/10.1016/j.atmosenv.2008.12.046

[20] Badarinath, K., Kharol, S.K., Kaskaoutis, D. and Kambezidis, H. (2007) Influence of Atmospheric Aerosols on Solar Spectral Irradiance in an Urban Area. Journal of Atmospheric and Solar-Terrestrial Physics, 69, 589-599. http://dx.doi.org/10.1016/j.jastp.2006.10.010

[21] Ramachandran, S. and Kedia, S. (2010) Black Carbon Aerosols over an Urban Region: Radiative Forcing and Climate Impact. Journal of Geophysical Research: Atmospheres (1984-2012), 115.

[22] Pathak, B., Kalita, G., Bhuyan, K., Bhuyan, P. and Moorthy, K.K. (2010) Aerosol Temporal Characteristics and Its Impact on Shortwave Radiative Forcing at a Location in the Northeast of India. Journal of Geophysical Research: Atmospheres (1984-2012), 115.

[23] Ye, B., Ji, X., Yang, H., Yao, X., Chan, C.K., Cadle, S.H., Chan, T. and Mulawa, P.A. (2003) Concentration and Chemical Composition of $\mathrm{PM}_{2.5}$ in Shanghai for a 1-Year Period. Atmospheric Environment, 37, 499-510. http://dx.doi.org/10.1016/S1352-2310(02)00918-4

[24] He, K., Yang, F., Ma, Y., Zhang, Q., Yao, X., Chan, C.K., Cadle, S., Chan, T. and Mulawa, P. (2001) The Characteristics of $\mathrm{PM}_{2.5}$ in Beijing, China. Atmospheric Environment, 35, 4959-4970. http://dx.doi.org/10.1016/S1352-2310(01)00301-6

[25] Draxler, R.R., Gillette, D.A., Kirkpatrick, J.S. and Heller, J. (2001) Estimating PM $_{10}$ Air Concentrations from Dust Storms in Iraq, Kuwait and Saudi Arabia. Atmospheric Environment, 35, 4315-4330. http://dx.doi.org/10.1016/S1352-2310(01)00159-5

[26] Meng, Z. and Lu, B. (2007) Dust Events as a Risk Factor for Daily Hospitalization for Respiratory and Cardiovascular Diseases in Minqin, China. Atmospheric Environment, 41, 7048-7058. http://dx.doi.org/10.1016/j.atmosenv.2007.05.006

[27] Hoffmann, C., Funk, R., Sommer, M. and Li, Y. (2008) Temporal Variations in $\mathrm{PM}_{10}$ and Particle Size Distribution during Asian Dust Storms in Inner Mongolia. Atmospheric Environment, 42, 8422-8431. http://dx.doi.org/10.1016/j.atmosenv.2008.08.014

[28] Wang, Y., Zhuang, G., Tang, A., Zhang, W., Sun, Y., Wang, Z. and An, Z. (2007) The Evolution of Chemical Components of Aerosols at Five Monitoring Sites of China during Dust Storms. Atmospheric Environment, 41, 1091-1106. http://dx.doi.org/10.1016/j.atmosenv.2006.09.015

[29] Yang, C.-Y., Chen, Y.-S., Chiu, H.-F. and Goggins, W.B. (2005) Effects of Asian Dust Storm Events on Daily Stroke Admissions in Taipei, Taiwan. Environmental Research, 99, 79-84. http://dx.doi.org/10.1016/j.envres.2004.12.009

[30] Yong-Seung, C., Hak-Sung, K., Kie-Hyon, P., Jugder, D. and Tao, G. (2005) Observations of Dust-Storms in China, Mongolia and Associated Dust Falls in Korea in Spring 2003. Water, Air, \& Soil Pollution: Focus, 5, 15-35. http://dx.doi.org/10.1007/s11267-005-0724-1

[31] Park, S.-U., Park, M.-S., and Chun, Y. (2010) Asian Dust Events Observed by a 20-m Monitoring Tower in Mongolia during 2009. Atmospheric Environment, 44, 4964-4972. http://dx.doi.org/10.1016/j.atmosenv.2010.08.014

[32] Shao, Y. (2008) Physics and Modelling of Wind Erosion. Springer Science \& Business Media, New York.

[33] Giri, D., Krishna Murthy, V. and Adhikary, P. (2007) The Influence of Meteorological Conditions on $\mathrm{PM}_{10}$ Concentrations in Kathmandu Valley.

[34] Yang, K.-L. (2002) Spatial and Seasonal Variation of $\mathrm{PM}_{10}$ Mass Concentrations in Taiwan. Atmospheric Environment, 36, 3403-3411. http://dx.doi.org/10.1016/S1352-2310(02)00312-6

[35] Oren, C.N. (2001) Clean Air and Interstate Transport: Seeing the Big Picture. The New York University Environmental Law Journal, 10, 196.

[36] Mkoma, S.L. and Mjemah, I.C. (2011) Influence of Meteorology on Ambient Air Quality in Morogoro, Tanzania. International Journal of Environmental Sciences, 1, 1107-1115.

[37] Aryal, R.K., Lee, B.-K., Karki, R., Gurung, A., Kandasamy, J., Pathak, B.K., Sharma, S. and Giri, N. (2008) Seasonal $\mathrm{PM}_{10}$ Dynamics in Kathmandu Valley. Atmospheric Environment, 42, 8623-8633. 
http://dx.doi.org/10.1016/j.atmosenv.2008.08.016

[38] Bae, G.-N., Lee, S.-B. and Park, S.-M. (2007) Vehicle-Related Fine Particulate Air Pollution in Seoul, Korea. Asian Journal of Atmospheric Environment, 1, 1-8. http://dx.doi.org/10.5572/ajae.2007.1.1.001

[39] Kim, K.-H., Pandey, S.K., Nguyen, H.T., Chung, S.-Y., Cho, S.-J., Kim, M.-Y., Oh, J.-M. and Sunwoo, Y. (2010) Long-Term Behavior of Particulate Matters at Urban Roadside and Background Locations in Seoul, Korea. Transportation Research Part D: Transport and Environment, 15, 168-174. http://dx.doi.org/10.1016/j.trd.2009.12.001

[40] Artınano, B., Salvador, P., Alonso, D., Querol, X. and Alastuey, A. (2004) Influence of Traffic on the $\mathrm{PM}_{10}$ and $\mathrm{PM}_{2.5}$ Urban Aerosol Fractions in Madrid (Spain). Science of the Total Environment, 334, 111-123. http://dx.doi.org/10.1016/j.scitotenv.2004.04.032 